\title{
Pengaruh Keputusan Investasi, Profitabilitas, Ukuran Perusahaan terhadap Nilai Perusahaan dengan Struktur Modal sebagai Variabel Intervening pada Perusahaan Properti dan Real Estate yang Terdaftar di BEI
}

\author{
Rizkya Paulita Nasution \\ Universitas Sumatera Utara \\ Rizkyapaulita.nst@gmail.com
}

\begin{abstract}
ABSTRAK
Tujuan penelitian menganalisis apakah keputusan investasi, profitabilitas dan ukuran perusahaan berpengaruh terhadap nilai perusahaan dengan struktur modal sebagai variabel intervening pada Perusahaan Properti Dan Real Estate yang terdaftar di BEI. Data yang digunakan adalah laporan tahunan dari masing-masing perusahaan sampel, yang dipublikasikan melalui website www.idx.go.id. Metode analisis yang digunakan dalam penelitian ini adalah metode asosiatif, dengan pengujian asumsi klasik dan analisis jalur. Metode pengambilan sampel yang digunakan adalah puposive sampling dengan total sampel sebanyak 10 perusahaan Property \& Real Estate yang terdaftar di BEI dan data dari tahun 2014 -2017. Hasil penelitian ini menunjukkan bahwa keputusan investasi tidak berpengaruh signifikan terhadap struktur modal. Profitabilitas dan ukuran perusahaan berpengaruh signifikan terhadap struktur modal pada Perusahaan Properti Dan Real Estate yang terdaftar di BEI, baik secara parsial dan simultan. Keputusan investasi berpengaruh signifikan terhadap nilai perusahaan. Profitabilitas, ukuran perusahaan dan struktur modal tidak berpengaruh signifikan terhadap nilai perusahaan pada Perusahaan Properti Dan Real Estate yang terdaftar di BEI. Keputusan investasi tidak berpengaruh terhadap nilai perusahaan dengan melalui struktur modal pada Perusahaan Properti Dan Real Estate yang terdaftar di BEI. Profitabilitas berpengaruh terhadap nilai perusahaan dengan melalui struktur modal pada Perusahaan Properti Dan Real Estate yang terdaftar di BEI.Ukuran perusahaan berpengaruh terhadap nilai perusahaan dengan melalui struktur modal pada Perusahaan Properti dan Real Estate yang terdaftar di BEI.
\end{abstract}

Kata Kunci : Keputusan Investasi, Profitabilitas, Ukuran Perusahaan, Nilai Perusahaan dan Struktur Modal 


\section{PENDAHULUAN}

Sebuah perusahaan didirikan tentunya mempunyai tujuan yang jelas. Hal yang paling mendasari didirikannnya suatu perusahaan adalah mendapatkan laba. Hal lain yang juga menjadi tujuan didirikannya perusahaan adalah memaksimalkan keuntungan pemegang saham, dan menaikkan harga jual saham di pasar modal apabila perusahaan tersebut telah go public. Kemajuan pasar modal di Indonesia mendorong perusahaan untuk terus meningkatkan nilai perusahaannya. Nilai perusahaan pada perusahaan yang telah go public biasanya tercermin dari harga sahamnya yang relatif tinggi dan stabil. Nilai perusahaan positif akan menarik investor untuk menginvestasikan dananya pada perusahaan yang bersangkutan.

Banyaknya investor yang mengincar saham suatu perusahaan akan memajukan perusahaan karena memperoleh suntikan dana yang dapat digunakan untuk kegiatan operasional. Nilai perusahaan di dalam penelitian ini diukur dengan menggunakan price earning ratio (PER). Terjadi penurunan rata-rata price earning ratio (PER) pada tahun 2016 sebesar 17,43x, dari tahun sebelumnya, maka hal ini akan berdampak pada menurunnnya tingkat kemakmuran pemegang saham. Penurunan price earning ratio (PER) disebabkan oleh beberapa faktor diantaranya yaitu keputusan investasi, profitabilitas, ukuran perusahan dam struktur modal.

Terjadi penurunan rata-rata debt to equity ratiopada tahun 2015 sebesar 98,83\% dan tahun 2016 sebesar 255,46\%, dari tahun sebelumnya, hal ini berdampak pada pendanaan dengan menggunakan utang yang terlalu tinggi akan meningkatkan risiko keuangan perusahaan dan pada akhirnya dapat mengakibatkan financial distress sehingga nilai perusahaan akan menurun.

\section{Keputusan Investasi}

\section{LANDASAN TEORI}

Sebagai bentuk pengelolahan dana guna memberikan keuntungan dengan cara menempatkan dana tersebut pada alokasi yang diperkirakan akan memberikan tambahan keuntungan. (Fahmi, 2015:3).

\section{Profitabilitas}

Kemampuan perusahaan untuk menghasilkan laba dibanding dengan modalperusahaan yang digunakan selama periode tertentu.(Riyanto, 2013)

\section{Ukuran Perusahaan}

Besar kecilnya perusahaan dilihat dari besarnya nilai ekuitas, nilai penjualan atau nilai total aset.(Riyanto, 2013).

\section{Struktur Modal}

Perimbangan antara hutang dengan modal yang dimiliki perusahaan.(Handayani, 2011).

\section{Nilai Perusahaan}

Persepsi investor terhadap perusahaan go public, yang sering dikaitkan dengan harga saham.(Adil, 2013)

\section{METODE PENELITIAN}


Penelitian asosiatif adalah yaitu penelitian yang menghubungkan dua variabel atau lebih. Populasi yang digunakan pada penelitian ini adalah perusahaan Properti\& Real Estate Yang Terdaftar di BEI pada tahun 2014 hingga tahun 2017 yang berjumlah 48 perusahaan. Sumber data tersedia dalam situs www.idnfinancials.com. Periode data penelitian ini meliputi data dari tahun 2014 sampai 2017.Teknik pengumpulan data dengan menggunakan metode dokumentasi, yaitu dengan mempelajari, mengklasifikasikan, dan menganalisis data sekunder berupa catatan-catatan, laporan keuangan tahunan maupun informasi yang terkait dengan lingkup penelitian ini. Pengolahan data menggunakan perangkat lunak SPSS 16.0For Windows. Analisis statisitk inferensial dalam penelitian ini meliputi: uji asumsi klasik, regresi analisis jalur, uji hipotesis.

\section{HASIL DAN PEMBAHASAN \\ Pengaruh Keputusan Investasi Terhadap Struktur Modal}

Hasil menunjukkan bahwa $t_{\text {hitung }}-0,280<\mathrm{t}_{\text {tabel }} 2,028$ dan signifikan $0,781>$ 0,05 , yang menyatakan keputusan investasi secara parsial tidak berpengaruh signifikan terhadap struktur modal. Keputusan investasi merupakan keputusan menyangkut pengalokasian dana berasal dari dalam dan luar perusahaan dalam berbagaip bentuk investasi. Keputusan investasi ditentukan seberapa besar nilai keputusan investasi. Semakin besar IOS suatusaham menyatakan saham tersebut semakin mahal terhadap pendapatan bersih per sahamnya. Berdasarkan teori agensi, jika rasio hutang terhadap saham relatif tinggi, maka pemegang saham tergoda melakukan substitusi aset, dengan meningkatkan risiko perusahaan. Risiko yang meningkat akan menguntungkan investor, sebaliknya risiko sangat dihindari oleh kreditur karena bunga yang diterima tetap sama besarnya, tidak peduli dengan keuntungan dari perusahaan. Untuk mencegah hal ini, kreditur membebankan bunga yang semakin tinggi dengan meningkatkan jumlah hutang. Hasil penelitian ini sesuai dengan penelitian Hermuningsih (2012), bahwa keputusan investasi secara parsial tidak berpengaruh signifikan terhadap struktur modal.

\section{Pengaruh Profitabilitas Terhadap Struktur Modal}

Hasil menunjukkan bahwat ${ }_{\text {hitung } 2,629>} \mathrm{t}_{\text {tabel }} 2,028$ dan signifikan $0,013<0,05$, yang menyatakan profitabilitassecara parsial berpengaruh signifikan terhadap struktur modal. Perusahaan dalam menggunakan pendanaan/internal bersumber laba ditahan, lalu menerbitkan hutang dan terakhir baru menerbitkan saham. Semakin tinggi keuntungan suatu perusahaan maka semakin besar dana internalnya sehingga penggunaan hutang akan berkurang. Hasil penelitian ini sesuai dengan penelitian Hermuningsih (2012), bahwa profitabilitas secara parsial berpengaruh signifikan terhadap struktur modal.

\section{Pengaruh Ukuran Perusahaan Terhadap Struktur Modal}

Hasil menunjukkan bahwat ${ }_{\text {hitung } 3,869>} \mathrm{t}_{\text {tabel }} 2,028$ dan signifikan $0,000<0,05$, yang menyatakan ukuran perusahaan secara parsial berpengaruh signifikan terhadap struktur modal. Ukuran perusahaan merupakan salah satu faktor yang dipertimbangkan perusahaan dalam menentukan seberapa besar kebijakan keputusan pendanaan. Ukuran perusahaan yang semakin besar membutuhkan pengeluaran dana yang semakin besar pula, baik itu dari kebijakan hutang atau modal sendiri dalam mempertahankan atau mengembangkan perusahaan. Hasil 
penelitian ini sesuai dengan penelitian Hermuningsih (2012), bahwa ukuran perusahaan secara parsial berpengaruh signifikan terhadap struktur modal.

\section{Pengaruh Keputusan Investasi Terhadap Nilai Perusahaan}

Hasil menunjukkan bahwa $t_{\text {hitung }} 2,372>t_{\text {tabel }} 2,030$ dan signifikan $0,023<0,05$, yang menyatakan keputusan investasi secara parsial berpengaruh signifikan terhadap nilai perusahaan. Keputusan investasi yang dilakukan akan sangat mempengaruhi nilai dari perusahaan yang mereka kelola karena berkembang atau tidaknya suatu perusahaan tergantung dari kelihaian dan ketajaman analisis dari manajemen untuk melakukan investasi-investasi baru sehingga dapat meningkatkan laba dari perusahaan. Jika perusahaan mampu menghasilkan laba yang tinggi, maka para pemilik modal atau investor akan tertarik untuk membeli saham perusahaan mereka dipasar modal dan akan mampu meningkatkan nilai perusahaan mereka di pasar modal. Hasil penelitian ini sesuai dengan penelitian Mayarina (2017), bahwa keputusan investasi secara parsial berpengaruh signifikan terhadap nilai perusahaan.

\section{Pengaruh Profitabilitas Terhadap Nilai Perusahaan}

Hasil menunjukkan bahwa $t_{\text {hitung }}-1,910<t_{\text {tabel }} 2,030$ dan signifikan $0,064>$ 0,05 , yang menyatakan profitabilitas secara parsial tidak berpengaruh signifikan terhadap nilai perusahaan. Profitabilitas merupakan kemampuan perusahaan menghasilkan laba, hal ini menandakan bahwa ketika profitabilitas meningkat pada perusahaan maka menandakan nilai perusahaan tersebut juga akan meningkat, dan dikarenakan investor melihat meningkatnya kinerja keuangan perusahaan. Hasil penelitian ini sesuai dengan penelitian Mayarina (2017), bahwa profitabilitas secara parsial tidak berpengaruh signifikan terhadap nilai perusahaan.

\section{Pengaruh Ukuran Perusahaan Terhadap Nilai Perusahaan}

Hasil menunjukkan bahwa thitung-0,619< $\mathrm{t}_{\text {tabel }} 2,030$ dan signifikan 0,540>0,05, yang menyatakan ukuran perusahaan secara parsial tidak berpengaruh signifikan terhadap nilai perusahaan Ukuran perusahaan merupakan gambaran perusahaan untuk menunjukkan keberhasilan sebuah perusahaan dalam mengelola kegiatan operasi. Perusahaan yang memiliki ukuran perusahaan yang besar akan cenderung lebih banyak menarik investor, hal ini dikarenakan investor lebih mudah mengakses ke pasar modal. Kemudahan itulah yang membuat perusahaan memiliki prospek yang baik sebagai alternatif obyek investasi.Hasil penelitian ini sesuai dengan penelitian Mayarina (2017), bahwa ukuran perusahaan secara parsial tidak berpengaruh signifikan terhadap nilai perusahaan.

\section{Pengaruh Struktur Modal Terhadap Nilai Perusahaan}

Hasil menunjukkan bahwa $t_{\text {hitung }} 1,881<t_{\text {tabel }} 2,030$ dan signifikan $0,068>0,05$, yang menyatakan struktur modal secara parsial tidak berpengaruh signifikan terhadap nilai perusahaan. Pengambilalihan perusahaan dan pembelian melalui utang dirancang untuk meningkatkan efisiensi dengan mengurangi arus kas bebas yang tersedia bagi para manajer, dengan kata lain pemilik sebuah perusahaan mempergunakan utang yang berjumlah relatif besar bagi perusahaan untuk membatasi manajernya, karena rasio utang yang tinggi akan meningkatkan ancaman kebangrutan untuk menjadi lebih berhati-hati dan tidak menghamburkanhamburkan uang para pemegang saham. Hasil penelitian ini sesuai dengan 
penelitian Mayarina (2017), bahwa struktur modalsecara parsial tidak berpengaruh signifikan terhadap nilai perusahaan.

\section{Pengaruh Keputusan Investasi Terhadap Nilai Perusahaan dengan Struktur Modal Sebagai Variabel Intervening}

Hasil menunjukkan bahwa besarnya pengaruh langsung (direct effect) adalah 0,368 sedangkan besar pengaruh tidak langsung (indirect effect) harus dihitung dengan mengalikan koefisien tidak langsungnya yaitu $-0,038 \times 0,354=-0,013$ atau total effect keputusan investasi ke nilai perusahaan $=0,368+(-0,038 \times 0,354)=$ 0,355 . Oleh karena nilai $\left(\mathrm{P}_{3}>\mathrm{P}_{1} \times \mathrm{P}_{2}\right)$ maka struktur modal tidak berfungsi sebagai variabel intervening. Hasil penelitian ini sesuai dengan penelitian Mayarina (2017), bahwa keputusan investasi berpengaruh signifikan terhadap nilai perusahaan dengan struktur modal sebagai intervening.

\section{Pengaruh Profitabilitas Terhadap Nilai Perusahaan dengan Struktur Modal Sebagai Variabel Intervening}

Hasil menunjukkan bahwa besarnya pengaruh langsung (direct effect) adalah 0,321 , sedangkan besar pengaruh tidak langsung (indirect effect) harus dihitung dengan mengalikan koefisien tidak langsungnya yaitu $0,358 \times 0,354=0,126$ atau total effectprofitabilitas ke nilai perusahaan $=-0,321+(0,358 \times 0,354)=0,195$. Oleh karena nilai $\left(\mathrm{P}_{3}<\mathrm{P}_{1} \times \mathrm{P}_{2}\right)$ maka struktur modal berfungsi sebagai variabel intervening. Hasil penelitian ini sesuai dengan penelitian Mayarina (2017), bahwa profitabilitas berpengaruh signifikan terhadap nilai perusahaan dengan struktur modal sebagai intervening.

\section{Pengaruh Ukuran Perusahaan Terhadap Nilai Perusahaan dengan Struktur Modal Sebagai Variabel Intervening}

Hasil menunjukkan bahwa besarnya pengaruh langsung (direct effect) adalah -0,111, sedangkan besar pengaruh tidak langsung (indirect effect) harus dihitung dengan mengalikan koefisien tidak langsungnya yaitu $0,515 \times 0,354=$ 0,182 atau total effectukuran perusahaan ke nilai perusahaan $=-0,111+(0,515 \mathrm{x}$ $0,354)=0,071$. Oleh karena nilai $\left(\mathrm{P}_{3}<\mathrm{P}_{1} \times \mathrm{P}_{2}\right)$ maka struktur modal berfungsi sebagai variabel intervening. Hasil penelitian ini sesuai dengan penelitian Mayarina (2017), bahwa ukuran perusahaan berpengaruh signifikan terhadap nilai perusahaan dengan struktur modal sebagai intervening.

\section{KESIMPULAN}

Berdasarkan analisis hasil studi dan pembahasan tentang flypaper effect pada unconditional grant dan pendapatan asli daerah terhadap belanja daerah pada Kabupaten Deli Serdang, dapat ditarik kesimpulan bahwa keputusan investasi tidak berpengaruh signifikan terhadap struktur modal. Profitabilitas dan ukuran perusahaan berpengaruh signifikan terhadap struktur modal pada Perusahaan Properti Dan Real Estate yang terdaftar di BEI, baik secara parsial dan simultan Keputusan investasi berpengaruh signifikan terhadap nilai perusahaan. Profitabilitas, ukuran perusahaan dan struktur modal tidak berpengaruh signifikan terhadap nilai perusahaan pada Perusahaan Properti Dan Real Estate yang terdaftar di BEI. Keputusan investasi tidak berpengaruh terhadap nilai perusahaan dengan melalui struktur modal pada Perusahaan Properti dan Real Estate yang terdaftar di BEI. Profitabilitasberpengaruh terhadap nilai perusahaan dengan melalui struktur 
modal pada Perusahaan Properti Dan Real Estate yang terdaftar di BEI. Dan ukuran perusahaanberpengaruh terhadap nilai perusahaan dengan melalui struktur modal pada Perusahaan Properti Dan Real Estate yang terdaftar di BEI.

\section{REFERENSI}

Adil, Ch. Muhammad, Nousheen Zafar dan Noman Yaseen, 2013. "Empirical Analysis of Determinants of Dividend Payout: Profitability and Liquidity", Interdisciplinary Journal of Contemporary Research in Bussiness Vol 3 No 1.

Ayuningtias, Dwi dan Kurnia. 2013. Pengaruh Profitabilitas Terhadap Nilai Perusahaan ; Kebijakan Dividen dan Kesempatan Investasi Sebagai Variabel Antara.

Brigham, Eugene dan Joel F. Houston, 2011, Manajemen Keuangan, Edisi 8, Buku Kedua, Alih Bahasa Dodo Suharto dan Herman Wibowo, Erlangga, Jakarta.

Erlina, 2013. Metodologi Penelitian, USU Press, Medan.

Evania, Sherlyn. (2018). Pengaruh Profitabilitas, Dividen Tunai, Dan Ukuran Perusahaan Terhadap Nilai Perusahaan Pada Perusahaan Manufaktur Yang Terdaftar Di Bursa Efek Indonesia.

Fahmi, Irham. (2015). Manajemen Investasi, Teori dan Soal Jawab. Edisi 2. Penerbit Salemba Empat, Jakarta.

Ghozali, Imam, 2015. Analisis Multivariat dengan Program SPSS, Edisi Ketiga, Badan Penerbit Universitas Diponegoro, Semarang.

Gitosudarmo, I. dan Basri. 2011. Manajemen Keuangan. Edisi III. Yogyakarta: BPFE.

Handayani, Bestasari Dwi. 2011." Pengaruh Struktur Modal terhadap Nilai Perusahaan pada Perusahaan sedang Bertumbuh yang Berbeda (Theory Agency)", UNS, jurnal Bisnis dan Ekonomi, volume 6, edisi 1

Harmono. (2018). Manajemen Keuangan. Berbasis Balanced Scorecard Pendekatan Teori, Kasus, dan Riset Penelitian.

Herawati, Titin, 2014. "Pengaruh Kebijakan Dividen, Kebijakan Hutang dan Profitabilitas terhadap Nilai Perusahaan", Universitas Padang.

Hermuningsih, Sri. (2012). Pengaruh Profitabilitas, Size Terhadap Nilai Perusahaan Dengan Sruktur Modal Sebagai Variabel Intervening.

Jayaningrat, Gusti A. Arya. (2017). Pengaruh Leverage, Profitabilitas, Likuiditas, Kebijakan Deviden, Kepemilikan Manajerial, Dan Kepemilikan Institusional Terhadap Nilai Perusahaan Pada Perusahaan Properti Dan Real Estate Di Bursa Efek Indonesia Tahun 2013-2015. e-journal S1 Ak Universitas Pendidikan Ganesha Jurusan Akuntansi Program S1 (Vol: 7 No: 1 Tahun 2017).

Jogiyanto, 2010. Analisa \& Design. Yogyakarta. Penerbit Andi Yogyakarta.

Lestari, Erna Yuliana. (2017). Pengaruh Likuiditas, Leverage, Dan Profitabilitas Terhadap Nilai Perusahaan Dengan Kebijakan Dividen Sebagai Variabel Moderating (Studi Pada Perusahaan Manufaktur yang Terdaftar di Bursa Efek Indonesia Periode 2011-2014). 